DOI: 10.34015/2523-4552.2019.1.07

УдК 343.8

Шумна Л. П.,

доктор юридичних наук, доцент,

завідувач кафедри теорії та історії

держави і права, конституційного права

Академії Державної пенітенціарної служби

e-mail:lari05@ukr.net

ORCID ID: 0000-0002-7708-296X

\title{
ПРОБЛЕМИ ДОТРИМАННЯ ТРУДОВИХ ПРАВ ЗАСУДЖЕНИХ В УКРАЇНІ У ВІДПОВІДНОСТІ ДО ЄВРОПЕЙСЬКИХ СТАНДАРТІВ
}

У статті розглянуто проблеми трудових прав засуджених у відповідності до європейських стандартів. Проведено аналіз дотримання трудових прав засуджених у місцях позбавлення волі за результатами моніторингових візитів національного превентивного механізму за підтримки Уповноваженого Верховної Ради України з прав людини. Вказано на грубі недоліки та порушення, що допускаються адміністрацією установ, що у свою чергу не відповідає нормам європейських стандартів. Запропоновано внести певні зміни в Постанову Кабінету Міністрів України від 30 листопада 2011 р. № 1232 «Деякі питання розслідування та обліку нещасних випадків, професійних захворювань та аварій на виробництві».

Ключові слова: праця засуджених; європейські стандарти; національний превентивний механізм; установи виконання покарань.

В статье рассматриваются проблемы трудовых прав осужденных в соответствии с европейскими стандартами. Проводится анализ соблюдения трудовых прав осужденных в местах лишения свободы по результатам мониторинговых визитов национального превентивного механизма при поддержке Уполномоченного Верховной Рады Украины по правам человека. Указано на грубые недостатки и нарушения, которые допускаются администрацией учреждений, которые в свою очередь не соответствуют нормам европейских стандартов. Предложено внести определенные изменения в Постановление Кабинета Министров Украины от 30 ноября 2011 № 1232 «Некоторые вопросы расследования и учета несчастных случаев, профессиональных заболеваний и аварий на производстве».

Ключевые слова: труд; труд осужденных; европейские стандарты; национальный превентивный механизм; учреждения исполнения наказаний.

Постановка проблеми. 3 прийняттям незалежності України почалися зміни в законодавстві країни, не виключенням стала і реформа пенітенціарної системи. Оскільки Україна прийняла курс направлений на до- 
тримання Європейських стандартів утримання в`язнів, нормативна база була переорієнтована із каральних методів на гуманний шлях виправлення та ресоціалізації особи.

Звісно змінився і підхід до праці засуджених. Особливо ці зміни стали суттєвими та кардинальними iз новаціями кримінально-виконавчого законодавства у 2016 році: визнанням права засуджених на працю, а не обов'язку, що відповідало не лише статті 43 Конституції України [1], а також міжнародним та європейським нормативно-правовим актам. Наприклад, в Загальній декларації прав людини, де в статті 23 зазначено що, кожна людина має право на працю, на вільний вибір роботи, на справедливі і сприятливі умови праці та на захист від безробіття [2]. Якщо звернутись до Мінімальних стандартних правил поводження із засудженими, а саме п. 71, то праця в'язня не повинна завдавати йому страждань. Усі засуджені в'язні повинні працювати відповідно до їхніх фізичних і психічних здібностей, засвідчених лікарем. На в'язнів слід покладати корисну роботу, достатню для того, щоб заповнити нормальний робочий день. Робота, якою забезпечуються в'язні, повинна бути такою, щоб підвищувати або давати їм кваліфікацію, що дозволила б їм зайнятися чесною працею після звільнення. В'язнів, які здатні мати 3 цього користь, особливо неповнолітніх, треба навчати корисних ремесел. В'язні повинні мати можливість виконувати роботу за своїм вибором, якщо це сумісно з правильним вибором ремесла і вимогами управління та дисципліни в закладі [3].

Одним із європейських нормативно-правових актів, що відобра- жають право засуджених на працю $є$ Рекомендація № R (2006)2 Комітету Міністрів Ради Європи від 11 січня 2006 року (далі Європейські пенітенціарні правила), де в частині II, пункті 26 вказано про трудову діяльність в'язнів [3].

Аналіз останніх досліджень і публікацій. Тематику правових аспектів праці засуджених досліджували такі вчені, як І.Г. Богатирьов, О. О. Бублік, Л. Ю. Величко, Т. А. Денисова, О. М. Джужа, Т. В. Дуюнова, В. В. Жернаков, І. Л. Жук, А. Ф. Зелінський, I. Б. Калініна, О. М. Кревсун, О. В. Лисодєд, О. М. Неживець, М. С. Пузирьов, А. Х. Степанюк, С. О. Стефанов, Ю. М. Ткачевський, С. В. Царюк, I. С. Яковець, М. М. Яцишин та інші. Хоча вищезазначені вчені зробили значний внесок в дослідження даної теми, але все одно залишаються питання, які потребують подальшого дослідження.

Постановка завдання. Метою даного дослідження $є$ аналіз дотримання трудових прав засуджених у місцях позбавлення волі у відповідності до Європейських стандартів утримання в`язнів за результатами моніторингових візитів національного превентивного механізму за підтримки Уповноваженого Верховної Ради України з прав людини та пошуки шляхів покращення дотримання трудових прав засуджених.

Для довідки. 4 листопада 1950 р. прийнято Європейську конвенцію про захист прав людини i основоположних свобод. Практично через півстоліття, а саме, 18 грудня 2002 р. прийнято Факультативний протокол до конвенції ООН проти катувань та інших жорстоких, нелюдських або таких, що принижують гідність, видів поводження і пока- 
рання (ФПКПК). Оскільки, 21 липня 2006 р. Україна ратифікувала Факультативний протокол, а 4 листопада 2012 р. набрав чинності Закон, що впроваджує Національний превентивний механізм в Україні, в структурі Секретаріату Уповноваженого Верховної Ради України з прав людини в тому ж 2012 році утворено спеціалізований структурний підрозділ - Департамент з питань реалізації національного превентивного механізму.

Національний превентивний механізм (НПМ) - це незалежний національний орган (або декілька органів), який створений і діє відповідно до Факультативного протоколу до Конвенції ООН проти катувань (ФПКПК), спрямований на регулярний моніторинг усіх місць несвободи $[4$, c. 4] з метою попередження у них жорстокого поводження 3 людьми, які там утримуються.
Виклад основного матеріалу. За результатами моніторингових візитів НПМ до установ виконання покарань спробуємо систематизувати та проаналізувати ряд виявлених порушень, що не відповідають міжнародним та європейським нормативно-правовим актам у сфері праці засуджених.

Перш все для переконливості майбутніх висновків проаналізуємо статистичні дані кількості засуджених у місцях позбавлення волі за період з 2014 по 2018 роки. Роком відліку взято саме 2016 - рік кардинальних новацій кримінально-виконавчого законодавства щодо праці засуджених. Тобто за 2 роки до та 2 роки опісля законодавчих змін зможемо порівняти цифровий вираз залучення засуджених до праці та динаміку розміру отримуваної ними заробітної плати.

(Таблиця 1)

\begin{tabular}{|c|c|c|c|c|c|c|}
\hline & 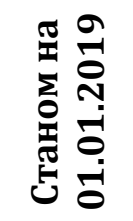 & 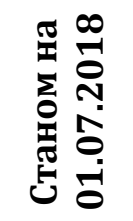 & 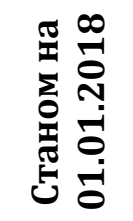 & 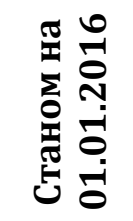 & 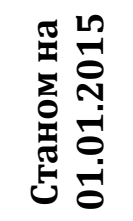 & 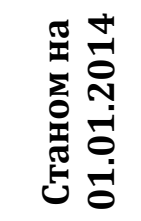 \\
\hline $\begin{array}{c}\text { Утрима- } \\
\text { ються в } \\
\text { УВП }\end{array}$ & 55078 & 56638 & 57100 & 69997 & 73431 & 126937 \\
\hline $\begin{array}{c}\text { Працезда- } \\
\text { тні }\end{array}$ & 22904 & 22233 & 24483 & 32095 & 32300 & 63803 \\
\hline $\begin{array}{c}\text { Працевла- } \\
\text { штовані }\end{array}$ & 8113 & 8169 & 9588 & 16226 & 18000 & 30297 \\
\hline $\begin{array}{c}\text { Середня } \\
\text { заробітна } \\
\text { плата } \\
\text { (грн.) }\end{array}$ & 1865 & 1738,7 & 1428,2 & 547,9 & 460,9 & 441,6 \\
\hline
\end{tabular}

(C) Шумна Л. П., 2019 
За даними таблиці (Таблиця 1) [5] приємно вражає тенденція до збільшення розміру заробітної плати за 4 роки майже в 4 рази, але привертають увагу разючі статистичні дані щодо зменшення охочих працювати за цей самий період теж у 4 рази. Засуджених, які бажають працювати 3 кожним роком стає менше, так у відсотковому відношенні між працездатними особами та працевлаштованими маємо наступні цифри: 2014 рік - 47,4 \%; 2015 рік - 56,25 \%; 2016 рік - 50,5 \%; 01.01.2018 року - 39,1\%; 01.07.2018 року - 36,7 \%; 01.01.2019 року $35,4 \%$.

Однозначно, аргументом для таких висновків $€$ зменшення майже в 2 рази в'язнів за звітний період, які утримуються в УВП, але чи тільки цей фактор є вирішальним? Саме це питання взято за основу для грунтовного аналізу дотримання трудових прав засуджених у місцях позбавлення волі.

Наприклад, якщо розглядати п. 2 Європейських пенітенціарних правил, де зазначено, що адміністрація пенітенціарної установи мусить прагнути надати ув'язненим достатньо корисної роботи [6], то можна зазначити, що тут частіше за все ситуація якраз навпаки. Особливо після того, як праця стала правом засуджених, проявляти бажання до працевлаштування стало набагато менше засуджених, а ніж передбачено робочих місць. Цей факт підтверджується моніторинговим візитом без попередження до Криворізької виправної колонії № 8016 січня 2019 року, де висвітлено такі факти, що на період перевірки в колонії відбувало покарання 681 особа та з них працевлаштовані лише 102 особи, хоча за сло- вами адміністрації, колонія має змогу забезпечити роботою всіх охочих засуджених. I це враховуючи те, що заробітна плата засуджених залежить від кількості відпрацьованих годин і складає від 2000 до 3000 грн з усіма відрахуваннями, що підтвердили самі засуджені. Дехто наголосив, що має змогу відправляти частину заробітку родичам на волю, щоб допомогти матеріально. Засуджені отримують індивідуальні засоби захисту: спецодяг, рукавиці, респіратори. Тобто умови праці більш ніж задовільні у порівняні із іншими установами [7]. Хоча проблемним залишається питання створення робочих місць в установах виконання покарань для усіх охочих працювати, особливо для осіб, які утримуються в приміщеннях камерного типу. Адміністрація установ, як правило, не в змозі залучити усіх бажаючих засуджених до оплачуваних робіт.

Як приклад можна навести моніторинговий візит у 2018 році до сектору максимального рівня безпеки (СМРБ) в Полтавській установі виконання покарань (№ 23), яка до того ж виконує функцію слідчого ізолятору. На момент візиту в установі відбували покарання 17 чоловіків. Опитані засуджені в цілому умовами утримання задоволені, відношенням до них адміністрації також, єдине на що скаржилися - відсутність можливості працювати та отримувати за це заробітну плату. Також було з'ясовано, що засуджені, які утримуються в установі, володіють різноманітними спеціальностями, такими як вироблення фігурних виробів з дерева. Але на превеликий жаль можливості займатися улюбленою справою засуджені не мають. 
Адміністрація установи пообіцяла, що вже влітку засудженим буде надана змога працювати на швейному виробництві (у разі, якщо вони все ж таки отримають необхідне обладнання, оскільки кімнату для нього вже виділено), однак засуджені мають бажання працювати і за іншими напрямками, наприклад, деревообробка або металоконструкції, тощо [8].

Згідно наказу Міністерства юстиції України за № $396 / 5$ від 07.03.2013 року «Про затвердження Інструкції про умови праці та заробітну плату засуджених до обмеження волі або позбавлення волі», який зареєстрований 11 березня 2013 р. за № 387/22919 праця засуджених до обмеження волі регулюється законодавством про працю, за винятком правил прийняття на роботу, звільнення з роботи, переведення на іншу роботу.

Відповідно до частини 3 статті 24 КЗПП, працівники (тобто особи, засуджені до позбавлення волі) мають допускатися до роботи за умови укладення трудового договору, оформленого наказом чи розпорядженням власника або уповноваженого ним органу, та повідомлення Державної фіскальної служби про прийняття працівника на роботу.

В ракурсі необхідності укладання із працевлаштованими засудженими трудових договорів актуальним $€$ питання їх паспортизації, оскільки особи, які не мають паспорта громадянина України, не можуть бути працевлаштовані легально, що у подальшому може вплинути на можливість застосування до них заохочувальних норм кримінальновиконавчого законодавства.

Розглядаючи п 6. Європейських пенітенціарних правил, де вказано, що ув'язнені можуть обирати вид діяльності, в якій вони хотіли б брати участь, у межах наявних можливостей, 3 урахуванням відповідного професійного відбору та вимог порядку і дисципліни [6], можна ствердити, що даний пункт не відображений в національному законодавстві, а отже взагалі не може бути виконаний. В кримінально-виконавчому кодексі в п. 2 ст. 118, зазначено, що засуджені до позбавлення волі, які мають заборгованість за виконавчими документами, зобов'язані працювати в місцях і на роботах, які визначаються адміністрацією колонії, до погашення такої заборгованості [9]. Тобто ця норма суперечить вищевказаному пункту Європейських пенітенціарних правил, оскільки ув'язнений не обирає вид діяльності, а навпаки працює там, де визначила адміністрація колонії.

Слід відмітити виявлений факт у 2015 році в Одеській області під час нічного моніторингового візиту НПМ до Чорноморської виправної колонії (№ 74). Під час візиту було встановлено, що адміністрація колонії застосовує жорстокі та принизливі заходи до тих засуджених жінок, які відмовляються від нічної та фактично безоплатної праці. Як правило, до таких заходів можна віднести погрозу не застосовувати пільгу у виді умовнодострокового звільнення від відбування покарання, яка передбачена статтею 81 Кримінального кодексу України, поміщення більш непокірних засуджених до дисциплінарного ізолятора за надуманими підставами, додаткові чергування у відділеннях соціально-психологічної служби, відмова у праві на побачення з рідними та користування крамницею, повна заборона перегляду каналів те- 
лебачення (з цією метою в установі складалися окремі списки засуджених по кожному відділенню соціально-психологічної служби за підписом директора підприємства колонії) [10, c. 294-295]. При цьому така інтенсивна праця практично не оплачувалась, що в свою чергу відображало той факт, що адміністрація установи, в першу чергу була зацікавлена у фінансовій складовій прибутку від виробництва установи, тому і змушувала працювати ув'язнених, не зважаючи на порушення їхніх прав. Це в свою чергу суперечить п. 8, де зазначено, що одержання фінансового прибутку від діяльності підприємств у виправних установах може бути корисним 3 огляду на підвищення стандартів, а також якості та доцільності професійної підготовки, проте інтереси ув'язнених не мусять підпорядковуватися цій меті [6].

Що ж стосовно п. 10, де зазначено, що у будь-якому випадку ув'язнені мусять отримувати за свою працю справедливу винагороду [6], то тут все не так однозначно.

Під час моніторингового візиту у 2015 році до Маріупольського виправного центру (№ 138), було виявлено, що при оплаті праці засудженим М. та У., які відпрацювали на пошитті рукавиць повну місячну норму часу (160 годин), а нарахована їм заробітна плата склала лише 105 грн кожному, що в одинадцять разів менше від мінімального розміру заробітної плати на той час [10, с. 292-293].

Візит у 2015 році до Приазовської виправної колонії (№ 107) також підтвердив системний характер порушень прав засуджених на гідну оплату праці. Так, затвердженим кошторисом установи на оплату праці засуджених, залишених для вико- нання робіт з господарського обслуговування, було передбачено недостатньо коштів, що не дозволяло нараховувати їм мінімально встановлену заробітну плату на місяць кожному. Фактично зазначеним засудженим нараховувалось від 0,25 (304,5 грн) до 0,8 (971,5 грн) ставки від мінімальної заробітної плати. Слід зазначити, що деякі засуджені, враховуючи безперервність технологічного циклу із забезпечення життєдіяльності установи (їдальня, санітарна частина, лазня тощо) фактично працювали не менш 8 годин на добу (враховуючи вихідні та святкові дні) та мали отримувати на місяць не менше 1218 грн.

Крім цього, під час моніторингового візиту від засуджених надходили неодноразові нарікання на малий розмір заробітної плати. Вибірковою перевіркою умов співпраці підприємства установи $з$ ТОВ «Олтекс» по наданню послуг з пошиття текстильних виробів за договором від 20.03.2015 було встановлено, що в калькуляціях до цього договору на пошиття утеплювачів до куртки та штанів частка заробітної плати у загальних витратах на виробництво зазначеної продукції складала близько $11 \%$ (утеплювач до куртки 4,51 грн, утеплювач до штанів - 3,64 грн). Тобто, для того, щоб отримати мінімальну заробітну платню, засудженим жінкам необхідно виконати норму виробітку - шити в день 13 утеплювачів до куртки. За результатами вивчення відповідної документації встановлено, що незважаючи на достатню кваліфікацію, жодна засуджена жінка не змогла виконати зазначену норму [10, с. 293].

У 2016 році в Оріхівській виправній колонії (№ 88) виявлено 
випадки, коли засуджені за місяць роботи на виробництві після всіх відрахувань отримували від 01 грн 11 коп. до 01 грн 67 коп., а зайняті на роботах з господарського обслуговування установи - від 73 до 86 грн Згідно із калькуляцією на швейну продукцію, що виготовляється в установі, собівартість утеплених жилетів складала 116 грн 15 коп., а закладена основна заробітна плата працівників - лише 3 грн 48 коп. (або 2,9 \% від виробничої собівартості), собівартість утеплених брюк - 149 грн. 32 коп., а заробітна плата - 5 грн 65 коп. (або 3,7 \%). Також в установі виявлено факти, коли засуджені перебували на робочих місцях у вихідні дні та нічний час. При цьому їх праця не обліковувалася та відповідно їм не була нарахована заробітна плата за цей період.

Згідно з інформацією Міністерства юстиції України, яка надійшла у відповідь на подання Уповноваженого Верховної Ради України з прав людини, розцінки на продукцію, що виробляється в установі, розраховуються відповідно до затверджених норм часу на виготовлення даного виду продукції, а норма часу встановлена на рівні середніх показників по області даної галузі виробництва. Разом із тим згідно з частиною першою статті 120 КВК України норми праці та розцінки повинні встановлюватися нормативно-правовими актами Міністерства юстиції України [11, c. 266].

2016 року у Білоцерківській виправній колонії (№ 35) на дільниці 3 пошиття мішків здійснювався подвійний облік виготовленої засудженими продукції. Так, офіційно за зміну на одного засудженого «закривалося» для нарахування заробітної плати по 1 тис. мішків. Продукція, яка виготовлялася понад цієї норми, офіційно не обліковувалася та складала приблизно від 100 до 3 тис. мішків на одного в'язня за зміну. За пошив необлікованої продукції засуджені отримували цигарки - від однієї цигарки за 100 мішків до 42 цигарок за 3 тис. мішків. Таким чином, виготовлення «лівої» продукції здійснювалося засудженими фактично безкоштовно. Відповідно до затверджених норми години виробітку та розцінки на виготовлення мішка для отримання законодавчо встановленої мінімальної заробітної плати (1450 грн) кожному засудженому необхідно було пошити за місяць 32 тис. мішків, що було неможливим унаслідок приховування від обліку основної частини продукції. Після здійснення відрахувань на особисті рахунки в'язнів щомісячно зараховувалося від 70 до 200 грн [11, с. 266].

Подібні ситуації спостерігались і в 2018 році, так в аналітичному звіті за результатами здійснення моніторингових візитів до установ Державної кримінально-виконавчої служби України за 2018 рік вказано, що під час візиту до ДУ «Житомирська виправна колонія (№ 4)», у табелях обліку відпрацьованого робочого часу працівників котельні за жовтень 2018 року було зазначено, що вони щоденно працюють по 0,72 години, тобто менше однієї години в день. Проте, при спілкуванні із цими особами вони повідомили, що працюють у три зміни по 8 годин на добу. Як наслідок, за 26 відпрацьованих людино-днів цим засудженим було нараховано заробіток у розмірі 566 грн 82 коп., з яких після здійснення всіх відрахувань залишилося лише 248 грн 59 коп. Для порівняння під час візиту до ДУ «Чер- 
каська виправна колонія (№ 62)» було з'ясовано, що до робіт у котельні установи залучаються вільнонаймані особи не з-поміж засуджених. Місячна заробітна плата цих осіб у першому кварталі 2018 року складала: прибиральник котельні $(0,5$ ставки) 1951 грн, електромонтер (повна ставка) - 4380 грн, слюсар (повна ставка) - 4990 грн.

Рівень заробітної плати засуджених-жінок в ДУ «Чорноморська виправна колонія (№ 74)» залежить від виконання норми виробітку усією бригадою. Проте, згідно із документацією установи стовідсотково норма виробітку не виконується, що свідчить або про те, що вона завищена, або про те, що праця в'язнів належним чином не фіксується [12, c. 47].

Аналіз калькуляцій (визначення ціни) продукції, яка виробляється в установах ДКВС України, засвідчив, що при їх складанні закладається низький рівень оплати праці робітників, які виготовляють цю продукцію. Так, відповідно до калькуляцій на продукцію, що виготовляється в ДУ «Житомирська виправна колонія (№ 4)», собівартість «пиломатеріалів обрізаних заданих розмірів» (1 м3) складає 3239 грн 90 коп., а закладена основна заробітна плата працівників - лише 140 грн 52 коп. (або 4,3 \% від виробничої собівартості), собівартість «дров паливних колотих» (1,48 м3) складає 2288 грн 54 коп., а заробітна плата - лише 71 грн 71 коп. (або 3,1 \%). Собівартість куртки ватної в ДУ «Черкаська виправна колонія (№ 62)» складає 215 грн 50 коп., а заробіток засуджених 3 цієї суми - лише 8 грн. 39 коп. (або 3,8 \% від собівартості продукції), собівартість костюма робочого складає 170 грн. 62 коп., а заробіток - лише 6 грн 24 коп. (або 3,6 \% від собівартості продукції). Такий підхід не стимулює засуджених до роботи [12, с. 48].

Згідно з інформацією опитаних осіб у Конотопському ВЦ (№ 130) у 2017 році, через низьку заробітну плату вони відмовляються працювати, що призводить до накладення на них дисциплінарних стягнень, які в подальшому також стають підставою для притягнення засуджених до кримінальної відповідальності за статтею 391 КК України. Так, засуджений П. за місяць роботи отримав лише 66 грн. 30 коп., що стало причиною його відмови від праці та як результат притягнення до дисциплінарної відповідальності [13, с. 231].

Правозахисники, провівши дослідження практичного застосування статті 391 КК України, дійшли висновку, що ця норма застосовується адміністрацією виправних закладів як інструмент тиску і маніпулювання засудженими, вимагання певних дій або матеріального збагачення. Є низка прикладів кримінальної розправи з боку персоналу виправних закладів з додатковим покаранням до 3 років позбавлення волі за принципову позицію засуджених у захисті своїх прав і законних інтересів, відбуваються переслідування за скарги засуджених в компетентні органи на дії (бездіяльність) персоналу виправних установ. За 8 років 800 засудженим додали 1-3 роки тюрми, зокрема. за відмову від робіт без оплати праці та інші дисциплінарні проступки. 19 жовтня 2018 року за ініціативи експертів Реанімаційного пакету реформ і Харківської правозахисної групи в парламенті зареєстрований Проект Закону про внесення змін до деяких законодав- 
чих актів України (щодо вилучення статті 391 Кримінального кодексу України) № 9228 [14].

3 вищенаведених фактів можна побачити, що засуджені не отримають справедливої винагороди за свою працю, який вони виконують під час відбування покарань.

Хоча $\epsilon$ і випадки, коли засуджені за свою працю не отримають заробітної плати, а навпаки мають борг перед установою. Так під час перевірки прокуратурою Дніпропетровської області Державної установи «Покровський виправний центр (№ 79)» було виявлено, що засуджені, які виконують норми виробітку, заробітної плати не отримують взагалі, а після відрахувань на комунально-побутове забезпечення, харчування та інші послуги мають борги перед виправним центром від 3 до 8 тисяч гривень [15].

У 2017 році під час візиту до Білоцерківської ВК (№ 35) до учасників моніторингової групи звернулися М., М. та П. зі скаргою на те, що, незважаючи на подані ними заяви до бухгалтерії установи про переведення частини їх особистих коштів на адресу родичів, зазначені операції проведено не було $[13$, с. 234], що $\epsilon$ порушенням п. 11, в якому вказано, що ув'язнені мусять мати можливість витрачати принаймні частину свого заробітку на придбання дозволених предметів для особистого користування та виділяти частину заробітку своїм родинам [6].

Якщо говорити про п. 13, де зазначено, що заходи з охорони здоров'я ув'язнених та техніки безпеки їхньої праці мусять бути не менш суворими, аніж заходи, які застосовуються щодо робітників на волі [6], то можна ствердити, що практично в кожній установі виконання покарань мають місце факти недостатнього забезпечення працюючих засобами індивідуального захисту, спецодягом та додатковим харчуванням. Усупереч вимогам законодавства засудженим, які працювали на дільницях зі шкідливими умовами праці (ливарне виробництво, електро- та газозварювальні роботи тощо), молоко не видавалось та не нараховувалася доплата за роботу зі шкідливими умовами праці.

Так, під час моніторингового візиту у 2015 році до Маріупольського випраного центру «№ 138» було встановлено, що умови праці засуджених на виробництві установи не відповідають встановленим вимогам. Унаслідок відсутності скла у вікнах цеху з переробки поліетиленової плівки та на швейній дільниці не дотримувався необхідний температурний режим. У виробничих приміщеннях бракувало як природного, так і штучного освітлення. Засуджені, які працюють на виробництві, не забезпечені спеціальним одягом [10, c. 292-293].

У 2015 році під час відвідування підприємства Стрижавської виправної колонії (№ 81) було виявлено, що практично на всіх виробничих ділянках установи, які пов'язані 3 процесом деревообробки та виготовлення деревного вугілля, засуджені працювали у шкідливих умовах праці, ними майже не використовувалися засоби захисту органів дихання (респіратори, пов'язки), а кількість цих засобів на підприємстві була недостатньою [10, с. 294].

Засобами індивідуального захисту засуджені у повній мірі не забезпечуються. Навіть за наявності таких засобів вони не завжди вико- 
ристовуються, що свідчить про слабкий контроль за технікою безпеки на виробництві. В'язні Казанківської ВК (№ 93) у 2017 році взагалі повідомили, що купують засоби захисту за власні кошти[13, с. 233].

Жінки в Уманській ВК (№ 129) інформували працівників Департаменту в 2017 році про випадки залучення їх до робіт з підняття вантажів, вага яких перевищує встановле- ні для них граничні норми підіймання і переміщення важких речей [13, c. 233].

Для довідки. Відповідно до Наказу Міністерства Охорони Здоров'я «Про затвердження Граничних норм підіймання і переміщення важких речей жінками» № 241 від 10.12.1993 року Граничні норми підіймання i переміщення важких речей жінками становлять [16]:

\begin{tabular}{|c|c|}
\hline Характер робіт & Граничнодопустима вага вантажу, кг \\
\hline $\begin{array}{c}\text { Підіймання і переміщення вантажів } \\
\text { при чергуванні з іншою роботою } \\
\text { (до } 2 \text { разів на годину) }\end{array}$ & 10 \\
\hline $\begin{array}{c}\text { Підіймання і переміщення вантажів } \\
\text { постійно протягом робочої змін }\end{array}$ & 7 \\
\hline \multicolumn{2}{|c|}{$\begin{array}{c}\text { Сумарна вага вантажу, який переміщується протягом кожної години робо- } \\
\text { чої зміни, не повинна перевищувати: }\end{array}$} \\
\hline з робочої поверхні & 350 кг \\
\hline з підлоги & 175 кг \\
\hline
\end{tabular}

\begin{tabular}{|c|c|c|c|c|}
\hline \multicolumn{5}{|c|}{ Граничні норми ваги вантажу (кг) } \\
\hline \multirow{2}{*}{$\begin{array}{c}\text { Календарний } \\
\text { вік, років }\end{array}$} & Короткочасна робота & \multicolumn{2}{|c|}{ Тривала робота } \\
\cline { 2 - 5 } & Юнаки & Дівчата & Юнаки & дівчата \\
\hline 14 & 5 & 2,5 & - & - \\
\hline 15 & 12 & 6 & 8,4 & 4,2 \\
\hline 16 & 14 & 7 & 11,2 & 5,6 \\
\hline 17 & 16 & 8 & 12,6 & 6,3 \\
\hline
\end{tabular}

Доречно також вказати Граничні норми підіймання та переміщення вантажів підлітками під час короткочасної та тривалої роботи [17].

Під час візиту в 2018 році до Полтавської виправної колонії «№ 64», моніторами виявлено, що на час перевірки працюють лише 211 із 625 засуджених. Вони задіяні на одному з трьох виробництв: зварочний цех, швейний цех та цех обробки деревного вугілля. Моніторингова гру- па відвідала цех обробки деревного вугілля: у цеху було важко дихати через недостатність вентиляції; підлога, стіни та стеля вкриті чорним пилом від вугілля; засуджені у цеху знаходились без спецодягу; рукавиць засуджені не одягали, хоча на вимогу їх показали моніторам. У зварювальних цехах робота не менш шкідлива, ніж у цеху з обробки вугілля: стоїть постійний сморід та гуркіт; засуджені працюють без спецодягу та наву- 
шників. У швейному цеху: стійкий та сильний запах клею; примусова вентиляція у приміщенні взагалі не працювала. Монітори одностайно відмітили, що знаходитися у таких умовах цілий робочий день важко, а місцями взагалі не можливо [18].

Враховуючи усі вище зазначені норми порушення законодавства доречно було б навести таке визначення, як катування. В справі Верховного Суду № 161/1372/16-к від 17 липня 2018 року, суддя наводить наступне визначення: катування визначається тяжкою формою нелюдського поводження із визначеною метою, тобто поводження, що спеціально заподіяно у жорстокій фізичній формі супроводжується фізичними та психічними стражданнями або грубо принижує людину перед іншими людьми чи змушує її діяти проти своєї волі або совісті. Тобто умови в яких доводиться працювати засудженим, можна назвати, як катування над ними [19].

Моніторинговий візит у 2018 році до Роменської виправної колонії «№ 56», дав змогу виявити факти порушення. Так, у приміщенні автослюсарної майстерні майже не потрапляло природнє світло. Засуджені, що підготовлювали автомобіль до фарбування, працювали без спецодягу та спецзасобів, натомість умови праці вирізнялися надмірним пилоу- творенням: стояв сильний запах фарби, засуджені знаходилися без масок та респіраторів. Подібна ситуація також спостерігається у деревообробному цеху та котельні: багато пилу та смороду; засуджені працюють без масок та рукавиць; стоїть постійний сильний гуркіт, відчувається вібрація, але навушники на пилорамі не видавали [20].

\section{Висновки.}

1. Підводячи підсумки вищезазначеного, можна ствердити, що в українських установах виконання покарань присутні систематичні факти порушення норм Європейських пенітенціарних правил у сфері трудової діяльності засуджених ув'язнених, які зафіксовані у візитах моніторами національного превентивного механізму та представниками прокуратури. Відповідно необхідно посилити контроль за додержанням законодавства про працю в установах виконання покарань компетентними державними органами.

2. Провести моніторинг укладення трудових договорів та договорів цивільно-правового характеру на виробництвах пенітенціарної системи 3 метою аналізу стану дотримання трудових прав засуджених та ув'язнених із числа працівників, визначення проблемних питань залучення засуджених до праці та шляхів їх вирішення.

\section{Список використаних джерел}

1. Конституція України: станом на 30 вересня 2016 р.: відповідає офіц. тексту. Харків : Право, 2016. 82 с.

2. Загальна декларація прав людини: Декларація від 10 грудня 1948 р., № 995_015. Офічійний вісник України. 2008. № 93. Ст.89.

3. Мінімальні стандартні правила ООН щодо поводження з ув'язненими: від 30 серпня 1955p. № 995-212 URL: http://zakon.rada.gov.ua/laws/show/995_212 (дата звернення: 29.01.2019).

4. Місця несвободи в Україні / Кол. авт. Харкыв : «ХІСД», 2012. 204 с. 
5. Кримінально-виконавча система України в 2018 році. Статистичний огляд (доповнений) URL: http://ukrprison.org.ua (дата звернення: 29.01.2019).

6. Європейські пенітенціарні правила: рекомендація Комітету Міністрів державучасниць від 11.01.2006 р. № R(2006)2. URL: https://zakon.rada.gov.ua/laws/show/ 994_032/ed20060111 (дата звернення: 03.02.2019).

7. Моніторинговий візит без попередження до Криворізької ВК № 80. URL: http://khpg.org/index.php?id=1548236618 (дата звернення: 31.01.2018).

8. Моніторинговий візит до «Полтавської УВП № 23». URL: http://khpg.org/index.php?id=1520272262 (дата звернення: 25.03.2019).

9. Кримінально-виконавчий кодекс України: Закон України від 11.07.2003 р. № 1129-IV. Відомості Верховної Ради України. 2004. № 3. 207 с.

10. Уповноважений Верховної Ради України з прав людини. щорічна доповідь Уповноваженого Верховної Ради України з прав людини про стан дотримання прав і свобод людини і громадянина в Україні. Київ : Права людини, 2016. 538 с.

11. Уповноважений Верховної Ради України з прав людини. щорічна доповідь Уповноваженого Верховної Ради України з прав людини про стан дотримання прав і свобод людини і громадянина в Україні. Київ : Права людини, 2017.627 с.

12. Жупанов Д. Аналітичний звіт за результатами здійснення моніторингових візитів до установ Державної кримінально-виконавчої служби України у 2018 році. Київ : Український інститут з прав людини, 2018. 64 с.

13. Уповноважений Верховної Ради України з прав людини. щорічна доповідь Уповноваженого Верховної Ради України з прав людини про стан дотримання прав і свобод людини і громадянина в Україні. Київ : Права людини, 2018. 661 с.

14. Правозахисники вимагають скасувати «андроповську» статтю у Кримінальному кодексі. URL: https://glavcom.ua/news (дата звернення: 02.02.19).

15. Виявлені грубі порушення в жіночому виправному центрі на Дніпропетровщині. URL: http://pk.khpg.org/index.php?id=1532955860 (дата звернення: 28.01.2019).

16. Про затвердження Граничних норм підіймання і переміщення важких речей жінками: Наказ МО3 від 10.12.1993 р. № 241. URL: https://zakon.rada.gov.ua/ laws/show/z0194-93 (дата звернення: 04.02.2.019).

17. Про затвердження граничних норм підіймання і переміщення важких речей неповнолітніми: Наказ МО3 від 22.03ю1996 р. № 59. URL: https://zakon.rada.gov.ua/ laws/show/z0183-96 (дата звернення: 04.02.2019).

18. Моніторинговий візит до Полтавської виправної колонії № 64. URL: http://khpg.org/index.php?id=1523191185 (дата звернення: 30.01.2019).

19. Рішення судової справи Верховного Суду України № 161/1372/16-к від 17.07.2018 p. URL: http://www.reyestr.court.gov.ua/Review/75473836 (дата звернення: 04.02.2019).

20. Моніторинговий візит до Роменської виправної колонії № 56. URL: http://khpg.org/index.php?id=1527082332 (дата звернення: 30.01.2019).

\section{References}

1. Konstituciya Ukrayini: stanom na 30 veresnya 2016 r.: vidpovidaye ofic. tekstu. (2016). Harkiv: Pravo [in Ukrainian].

2. Zagalna deklaraciya prav lyudini: Deklaraciya vid 10 grudnya 1948 r., N 995_015. Oficijnij visnik Ukrayini. 2008. N 93. St.89 [in Ukrainian].

3. Minimalni standartni pravila OON shodo povodzhennya z uv'yaznenimi: vid 30 serpnya 1955r. N 995-212 URL: http://zakon.rada.gov.ua/laws/show/995_212 (data zvernennya: 29.01.2019) [in Ukrainian].

4. Miscya nesvobodi v Ukrayini (2012). Harkyv: «HISD» [in Ukrainian]. 
5. Kriminalno-vikonavcha sistema Ukrayini v 2018 roci. Statistichnij oglyad (dopovnenij) URL: http://ukrprison.org.ua (data zvernennya: 29.01.2019) [in Ukrainian].

6. Yevropejski penitenciarni pravila: rekomendaciya Komitetu Ministriv derzhavuchasnic vid 11.01.2006 r. N R(2006)2. URL: https://zakon.rada.gov.ua/laws/show/ 994_032/ed20060111 (data zvernennya: 03.02.2019) [in Ukrainian].

7. Monitoringovij vizit bez poperedzhennya do Krivorizkoyi VK N 80. URL: http://khpg.org/index.php?id=1548236618 (data zvernennya: 31.01.2018) [in Ukrainian].

8. Monitoringovij vizit do «Poltavskoyi UVP N 23». URL: http://khpg.org/ index.php?id=1520272262 (data zvernennya: 25.03.2019) [in Ukrainian].

9 . Kriminalno-vikonavchij kodeks Ukrayini: Zakon Ukrayini vid 11.07.2003 r. N 1129-IV. Vidomosti Verhovnoyi Radi Ukrayini. 2004. N 3. 207 [in Ukrainian].

10. Upovnovazhenij Verhovnoyi Radi Ukrayini z prav lyudini. shorichna dopovid Upovnovazhenogo Verhovnoyi Radi Ukrayini z prav lyudini pro stan dotrimannya prav i svobod lyudini i gromadyanina v Ukrayini. Kiyiv: Prava lyudini. (2016) [in Ukrainian].

11. Upovnovazhenij Verhovnoyi Radi Ukrayini z prav lyudini. shorichna dopovid Upovnovazhenogo Verhovnoyi Radi Ukrayini z prav lyudini pro stan dotrimannya prav i svobod lyudini i gromadyanina v Ukrayini. Kiyiv: Prava lyudini. (2017) [in Ukrainian].

12. Zhupanov D. Analitichnij zvit za rezultatami zdijsnennya monitoringovih vizitiv do ustanov Derzhavnoyi kriminalno-vikonavchoyi sluzhbi Ukrayini u 2018 roci. Kiyiv: Ukrayinskij institut z prav lyudini. (2018) [in Ukrainian].

13. Upovnovazhenij Verhovnoyi Radi Ukrayini z prav lyudini. shorichna dopovid Upovnovazhenogo Verhovnoyi Radi Ukrayini z prav lyudini pro stan dotrimannya prav i svobod lyudini i gromadyanina v Ukrayini. Kiyiv: Prava lyudini. (2018) [in Ukrainian].

14. Pravozahisniki vimagayut skasuvati «andropovsku» stattyu u Kriminalnomu kodeksi. URL: https://glavcom.ua/news (data zvernennya: 02.02.19) [in Ukrainian].

15. Viyavleni grubi porushennya $\mathrm{v}$ zhinochomu vipravnomu centri na Dnipropetrovshini. URL: http://pk.khpg.org/index.php?id=1532955860 (data zvernennya: 28.01.2019) [in Ukrainian].

16. Pro zatverdzhennya Granichnih norm pidijmannya i peremishennya vazhkih rechej zhinkami: Nakaz MOZ vid 10.12.1993 r. N 241. URL: https://zakon.rada.gov.ua/ laws/show/z0194-93 (data zvernennya: 04.02.2.019) [in Ukrainian].

17. Pro zatverdzhennya granichnih norm pidijmannya i peremishennya vazhkih rechej nepovnolitnimi: Nakaz MOZ vid 22.03yu1996 r N 59. URL: https://zakon.rada.gov.ua/laws/show/z0183-96 (data zvernennya: 04.02.2019) [in Ukrainian].

18. Monitoringovij vizit do Poltavskoyi vipravnoyi koloniyi $N$ 64. URL: http://khpg.org/index.php?id=1523191185 (data zvernennya: 30.01.2019) [in Ukrainian].

19. Rishennya sudovoyi spravi Verhovnogo Sudu Ukrayini N 161/1372/16-k vid 17.07.2018 r. URL: http://www.reyestr.court.gov.ua/Review/75473836 (data zvernennya: 04.02.2019) [in Ukrainian].

20. Monitoringovij vizit do Romenskoyi vipravnoyi koloniyi N 56. URL: http://khpg.org/index.php?id=1527082332 (data zvernennya: 30.01.2019) [in Ukrainian]. 
L. Shumna, Doctor of Law, Associate Professor, Head of the Department of Theory and History of State and Law, Constitutional Law of the Academy of the State Penitentiary Service

e-mail: lari05@ukr.net; ORCID ID: 0000-0002-7708-296X

\section{Problems of accession of labor rights of proceedings in Ukraine in conformity with European standards}

The paper considers about rights of convicts in accordance with European standards. The article focus on the labor of prisoners, which are enshrined in the Standard Minimum Rules for the Treatment of Prisoners. Separate consideration is given to the labor activities of prisoners, which is specified by European penitentiary rules.

The article analyzes the observance of the labor rights of convicts in places of detention based on the results of monitoring visits of the national preventive mechanism with the support of the Human Rights Ombudsperson.

Gross flaws and vidations allowed by the administration of the institutions are indicated, that does not mutt the norms of European standards.

The paper states it is necessary to strengthen the control over the observance of labor legislation in penitentiary institutions by the competent state authorities. It has been established that national legislation does not provide the possibility of involving convicted people as entrepreneurs which does not comply with the European penitentiary rules.

The article offense to make certain changes in the Decree of the Cabinet of Ministers of Ukraine dated November 30, 2011, No. 1232 «Some Issues of Investigation and Accounts of Accidents, Occupational Diseases and Accidents at Work».

Keywords: work of convicts; European standards; national preventive mechanism; penal institutions.

Надійшла до редакції 05.03.2019 